\title{
The silica road: Field trip notes
}

\author{
María Soto ${ }^{1,2}$, Bruno Gómez de Soler ${ }^{1,2}$ \\ 1. Institut Català de Paleoecologia Humana i Evolució Social (IPHES). C/Marcel.lí Domingo s/n (Edifici W3), \\ Campus Sescelades, 43007, Tarragona, Spain. \\ 2. Àrea de Prehistoria, Universitat Rovira i Virgili (URV), Avinguda Catalunya, 35, 43002, Tarragona, Spain. \\ Email: Soto: sotoquesadamaria@gmail.com; Gómez de Soler: bgomez@iphes.cat
}

\begin{abstract}
:
During the 10th International Symposium on Knappable Materials (ISKM) held at Barcelona (Spain) in 2015, a field trip along “The Silica Road” was organized. It included the visit to different chert outcrops located along the Montsant Massif (Tarragona, NE Iberian Peninsula), and to the Middle Palaeolithic site of the Abric Romaní (Capellades, Barcelona), as important locations for the Prehistory of the North East of the Iberian Peninsula.

This paper present some keynotes distributed to the symposium attendants. It consists on: 1) a brief geological framework of the Montsant Massif, located at the southern margin of the Catalan Central Depression. It includes the definition of their Palaeozoic to Cenozoic depositional sequence and the localization of some points of interests with panoramic views and source areas where Tertiary chert nodules were available. They represent a significant focus for the raw materials procurement of several Paleolithic occupations since Lower Pleistocene. 2) A general presentation of the Middle Palaeolithic site of the Abric Romaní site, including a brief reference of the three research phases initiated at the beginning of 20th Century, the description of its 50 meters stratigraphic sequence, where 27 archaeological levels have been identified dating since 110 to $39 \mathrm{ka} \mathrm{BP}$, and some of the main traits of the archaeological assemblages recovered.
\end{abstract}

Keywords: lithic raw materials; chert; Montsant Massif; Ulldemolins Complex; Middle Palaeolithic; Abric Romaní

\section{Introduction}

A field trip was organized during the $10^{\text {th }}$ International Symposium on Knappable Materials held at Barcelona in 2015.

This field trip, $11^{\text {th }}$ September 2015, involved the visit to some locations of the Silica Road (Montsant Massif, Tarragona) and to the Middle Palaeolithic site of the Abric Romaní (Capellades, Barcelona).

Both represent important localities of the Prehistory of the NE of Iberian Peninsula. The first one constitutes one of the main lithic procurement areas during the Palaeolithic, as it is demonstrated by the continuous occupation of the area since the Lower Pleistocene. By the

Published by the School of History, Classics and Archaeology, University of Edinburgh ISSN: 2055-0472. URL: http://journals.ed.ac.uk/lithicstudies/

This work is licensed under a Creative Commons Attribution 2.5 UK: Scotland License. 
other side, the Abric Romaní represents one of the most complete archaeological sequences yielding Middle Palaeolithic occupations.

\section{The Montsant Massif: Geological context}

The Montsant Massif, formed up by Tertiary aged materials, is located in the southern margin of the Catalan Central Depression and is adjacent to the southwestern limit of the Prades Range (Catalanids), constituted by Paleozoic and Mesozoic materials.

The Montsant Massif shows a depositional sequence of three geological formations: (1) Paleozoic basement, formed up by slates and grey sandstones; (2) Mesozoic substratum, formed up by Triassic materials and composed by limestones, conglomerates and sandstones and dolomitic materials, where cherts are scarce but continued distributed; and (3) Cenozoic coverage, irregulary represented and formed up by red lutites, sandstones, evaporites and carbonates levels (Colombo 1986).

The Cenozoic coverage (Figure 1) presents a stratigraphic sequence named as the Cornudella Group, where the Ulldemolins Complex and La Morera Formation could be identified. Both lithostratigraphic units present numerous chert outcrops, defining a rich and predictable landscape for lithic procurement that favored a dense and continuous prehistoric occupation studied since the beginning of the $20^{\text {th }}$ century (Figure 2 ).

\section{The Silica Road}

Along the way down "The Silica Road” attendants could observe several localities, chert outcrops and historical quarries that characterize the area as an ideal landscape for performing geological practices.

Three stops were programmed on this field trip (Figure 3) in order to understand the geological features, identify the main sedimentological and paleoenvironmental conditions and observe the outcropping raw materials used by the prehistoric populations.

\subsection{First stop: The Montsant Overlook (Ulldemolins, Tarragona)}

This place offered a general and beautiful vision of the western sector of the Montsant Massif and its contact with the Cenozoic coverage and the Prades Mountains.

The disposition of these mountains let to identify a curious and irregular downdip of the conglomerates levels, traditionally called Roca Llaurada (Figures 4 and 5). It consists an angular discordance by tectonic movements that put the conglomerates in contact with the underlying levels (Colombo \& Vergés 1992)

\subsection{Second stop: Ulldemolins Cherts (Ulldemolins, Tarragona)}

At this locality abundant nodular cherts could be found (Figure 6A-C). Gypsiferous red lutites and secondary gypsums with frequent anhydrite are the enclosing rocks of nodular chert. These cherts are product of an early diagenesis where microcrystalline quartz and positive elongated fibrous quartz replace the gypsiferous pseudomorphs.

Nodular cherts could be also found enclosed in gypsiarenites and gypsilutites and primary lenticular gypsums along the Ulldemolins Complex we visited (Figure 6D).

The high levels of lithic resources and its wide scattering in the area forces to the study of their enclosing lithofacies and depositional models help for defining the different sourceareas frequented by the prehistoric population. 

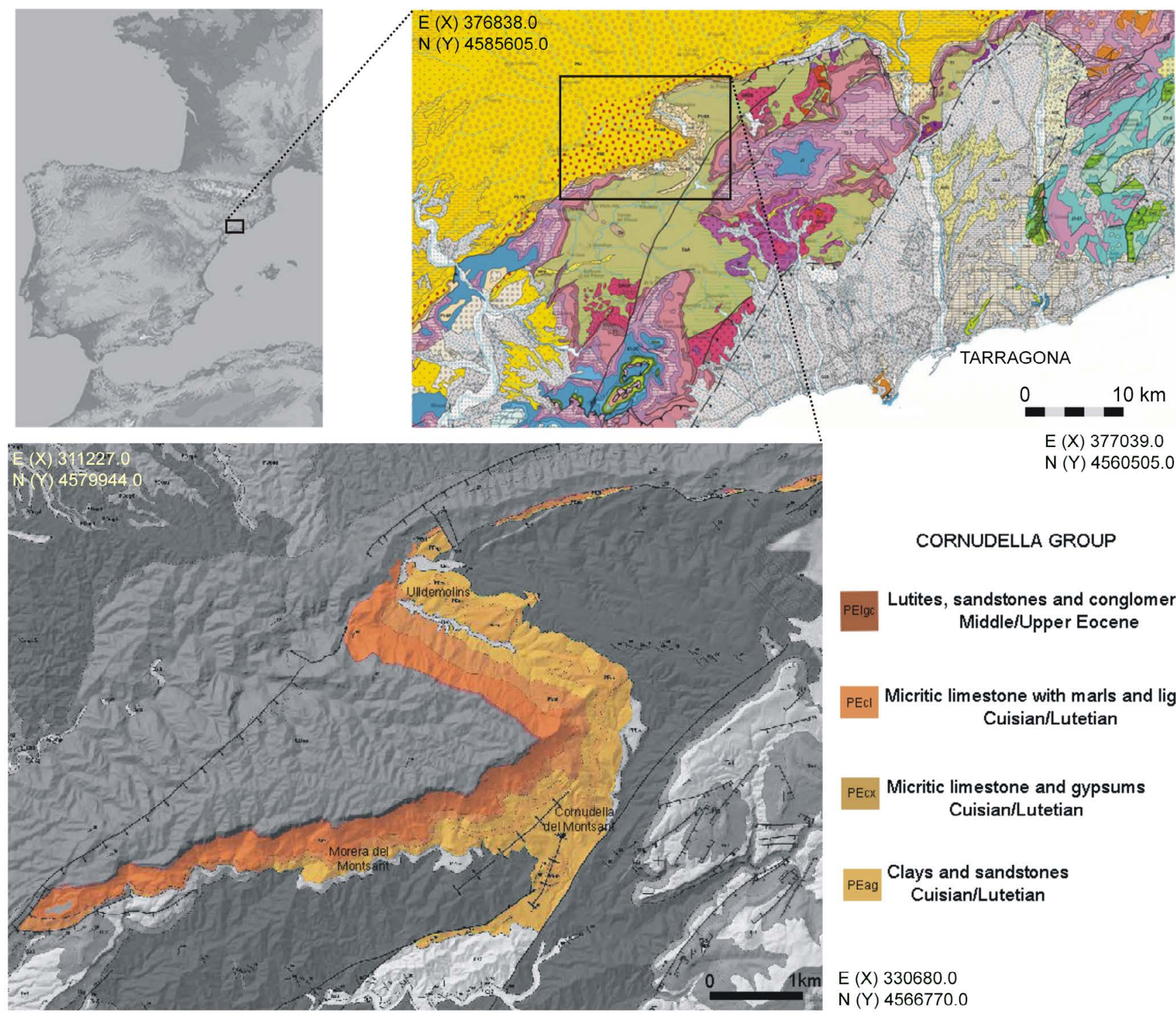

Figure 1. Detail of the geologic map of the Monstant Massif location and the Cenozoic coverage associated with the Cornudella Group (Geological maps, 1:50,000 - UTM 31N (ETRS 89), modified from ICGC (2016a)).

Journal of Lithic Studies (2016) vol. 3, nr. 2, p. 761-777

doi:10.2218/jls.v3i2.1873 


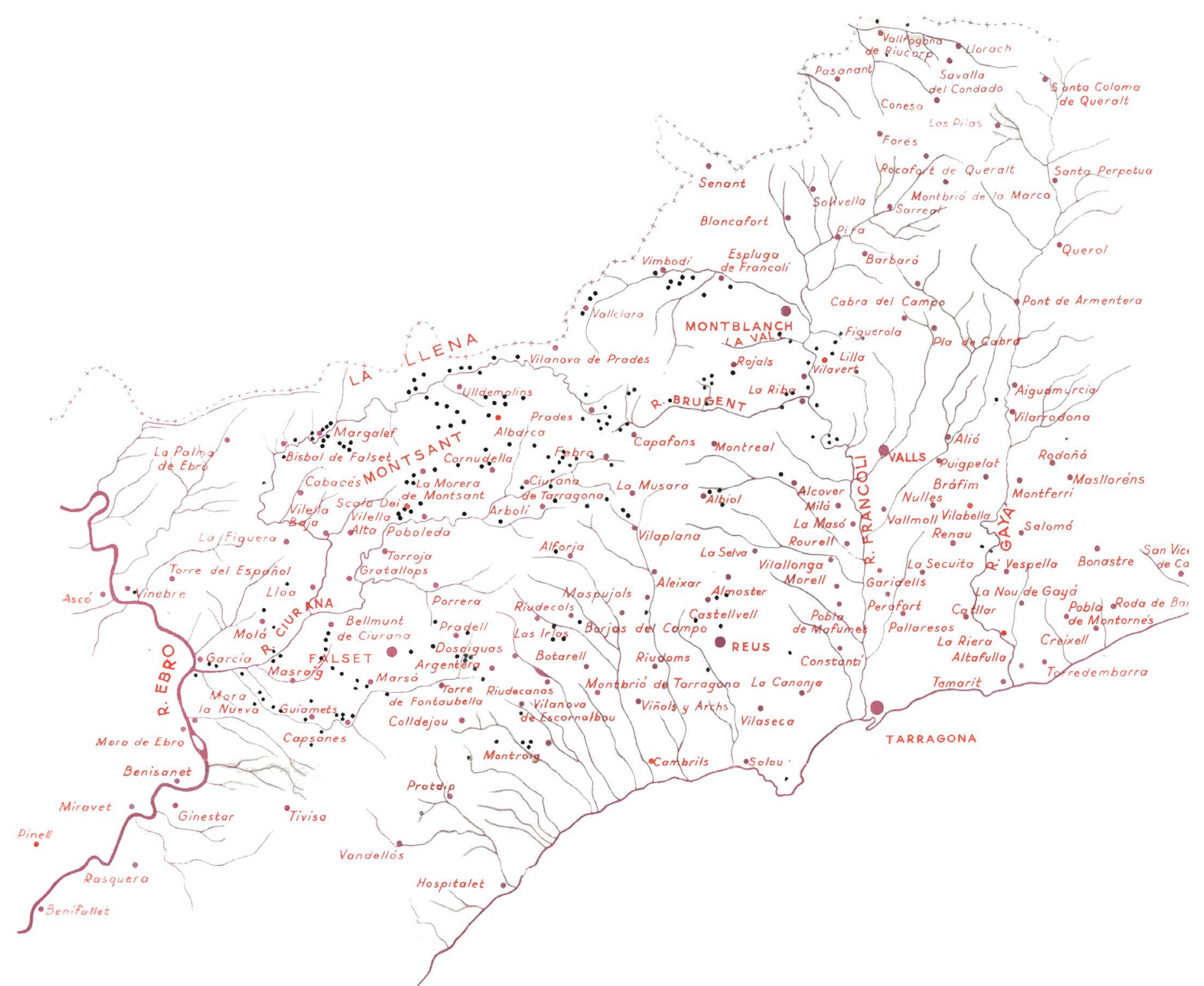

Figure 2. Map of the chert outcrops and archaeological sites (black dots) located in the area during the first half of the $20^{\text {th }}$ century (Vilaseca 1953: 425). 


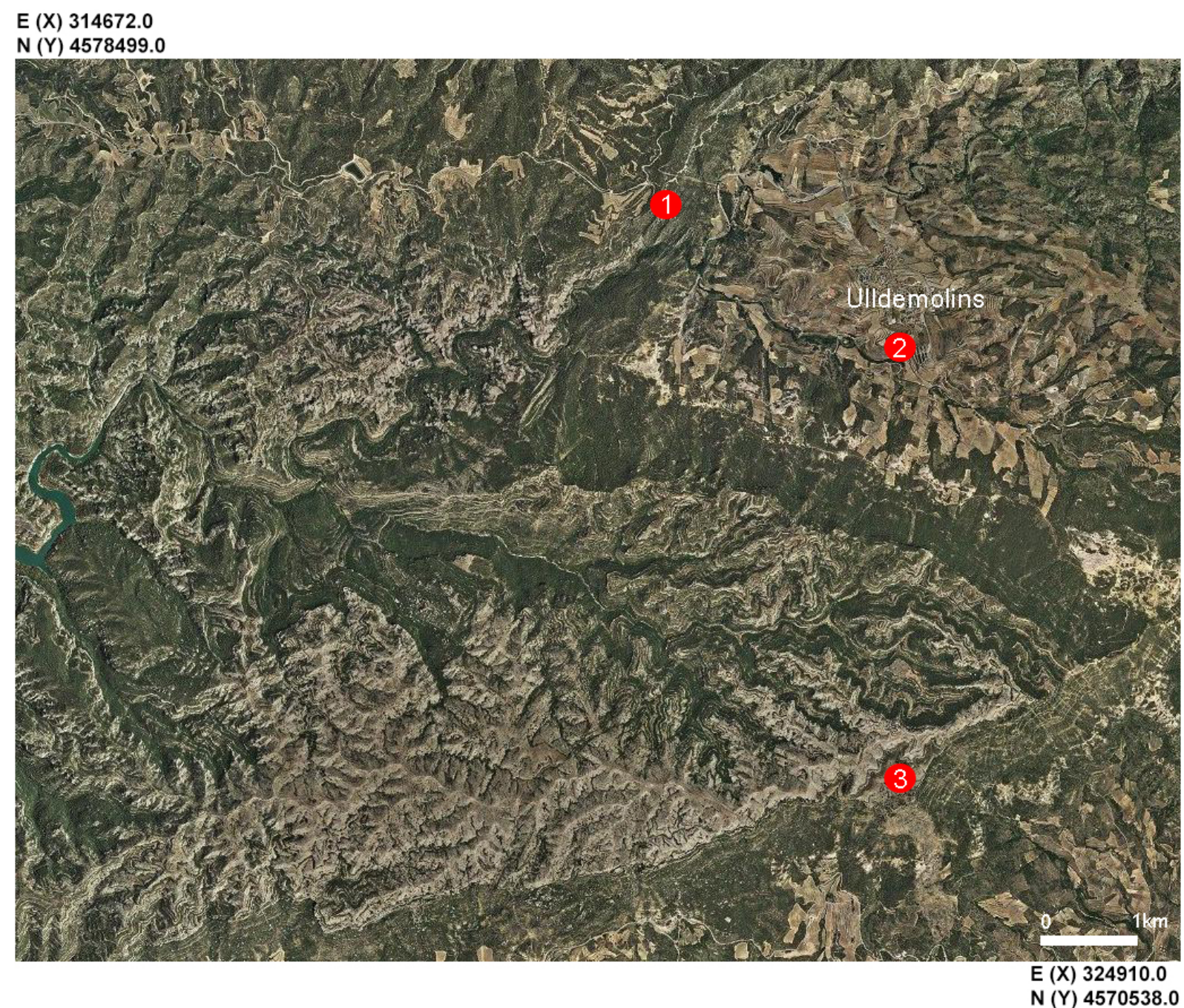

Figure 3. Itinerary of The Silica Road trip: 1-The Montsant Overlook; 2-Ulldemolins Cherts; 3- The Ulldemolins Complex. (Orthophoto, 1:25,000 - UTM 31N (ETRS 89), modified from ICGC (2016b))

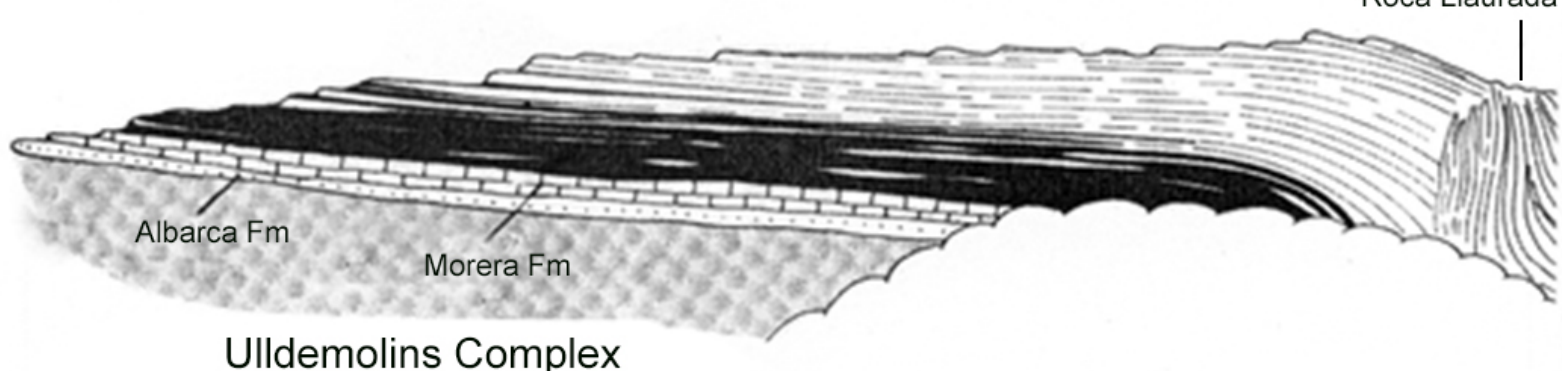

Figure 4. Scheme showing the layout of the levels of Montsant Massif levels and Roca Llaurada downdip. (Modified from Colombo \& Vergés 1992) 

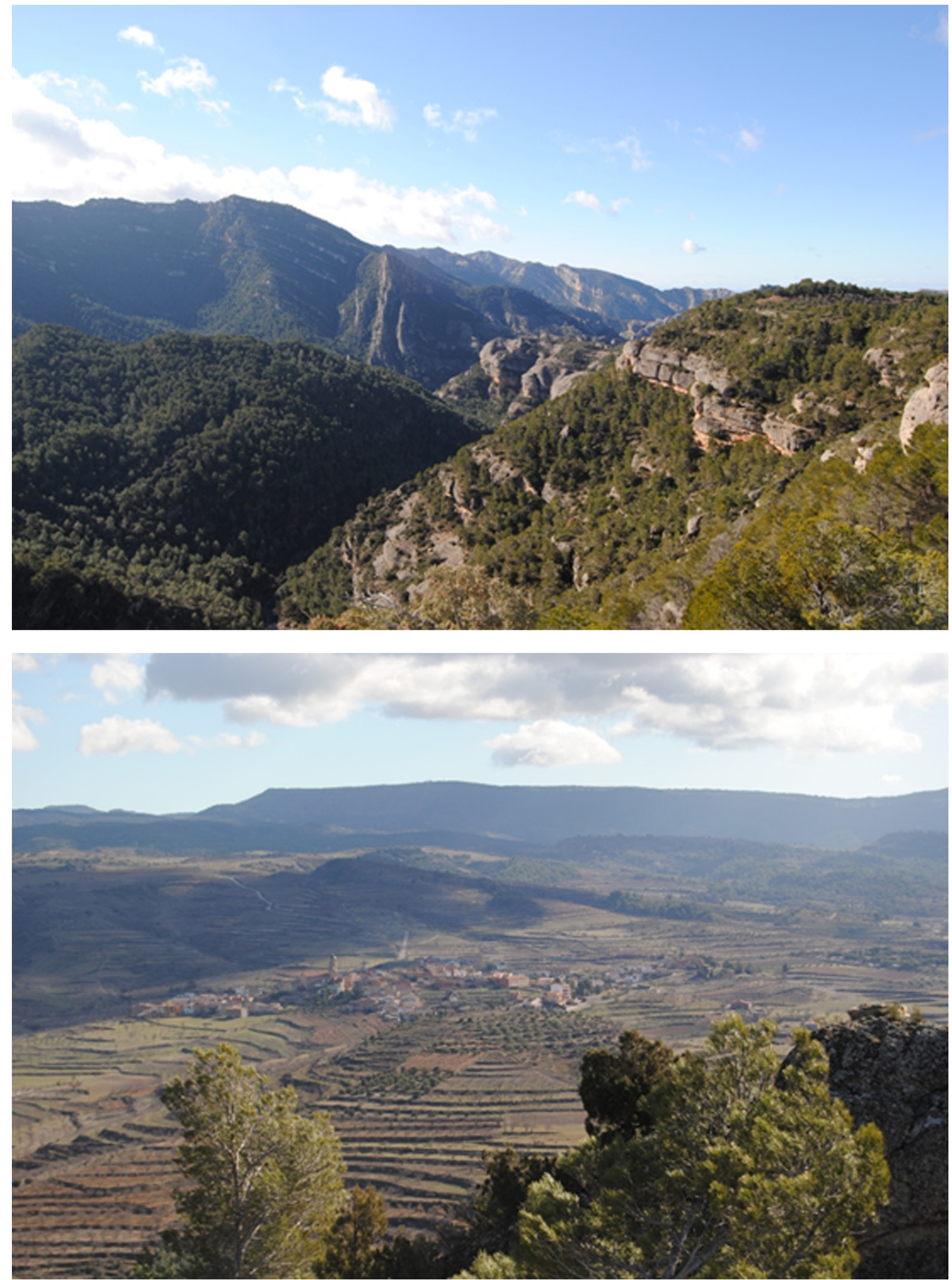

Figure 5. Panoramic views from the Montsant Overlook. 
$E(X) 322669.0$

\section{$\mathrm{N}(\mathrm{Y}) \mathbf{4 5 7 6 0 1 2 . 5}$}
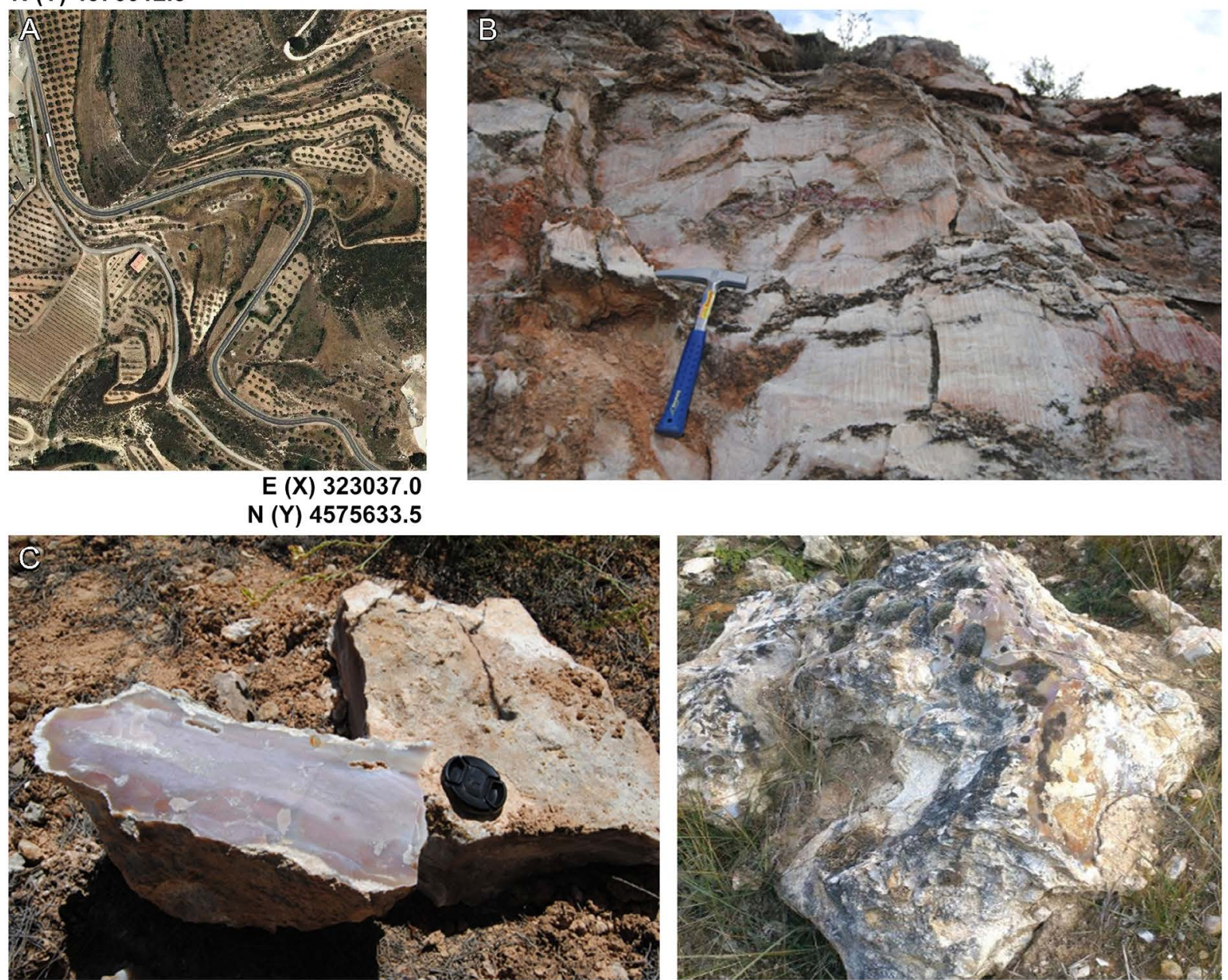
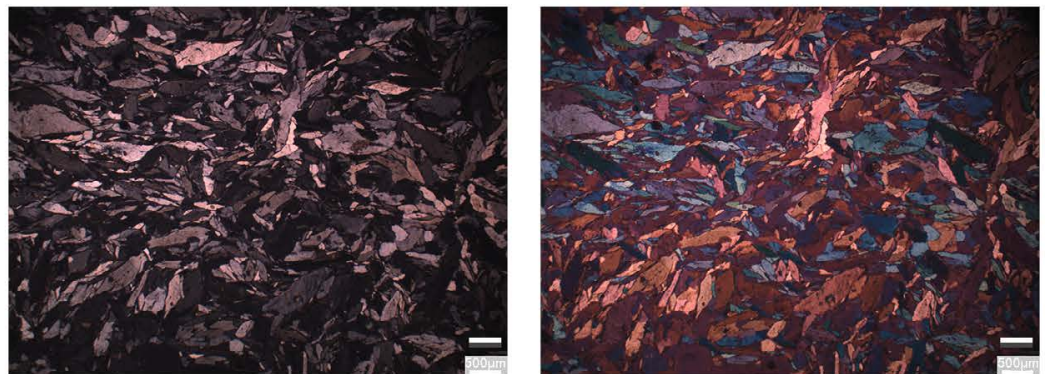

Figure 6. A) Area of the second stop of the Silica Road Trip (UTM 31N-ETRS89). B-C) Outcrop section and details of the Ulldemolins chert nodules. D) Thin sections images from an Ulldemolins chert showing their high content of gypsum crystals (Soto 2015).

\subsection{Third stop: The Ulldemolins Complex (Cornudella del Monstsant, Tarragona)}

The Ulldemolins Complex is formed up by an alternation of red lutites, sandstones, grey marls and evaporites (Anadón et al. 1989). It is dated on Lutetian (Lower-Upper Eocene) and overlies the Mediona Fm that is composed by lutites and sandstones.

This point presents a lithostratigraphic sequence composed from base to top, by: 1.Red lutites; 2. Massive gypsum; 3. Lutites and nodular gypsum; 4. nodular carbonates; 5. dolomitized lacustrine carbonates; 6. Sandy grey lutites; 7. Sandstones; 8. Lutites (Figure 7)

This sequence is related to centered and marginal sections of shallow saline lacustrine environments in arid climates, sabhka type, with frequent lateral variations due to quick progressive and retrogressive events. 


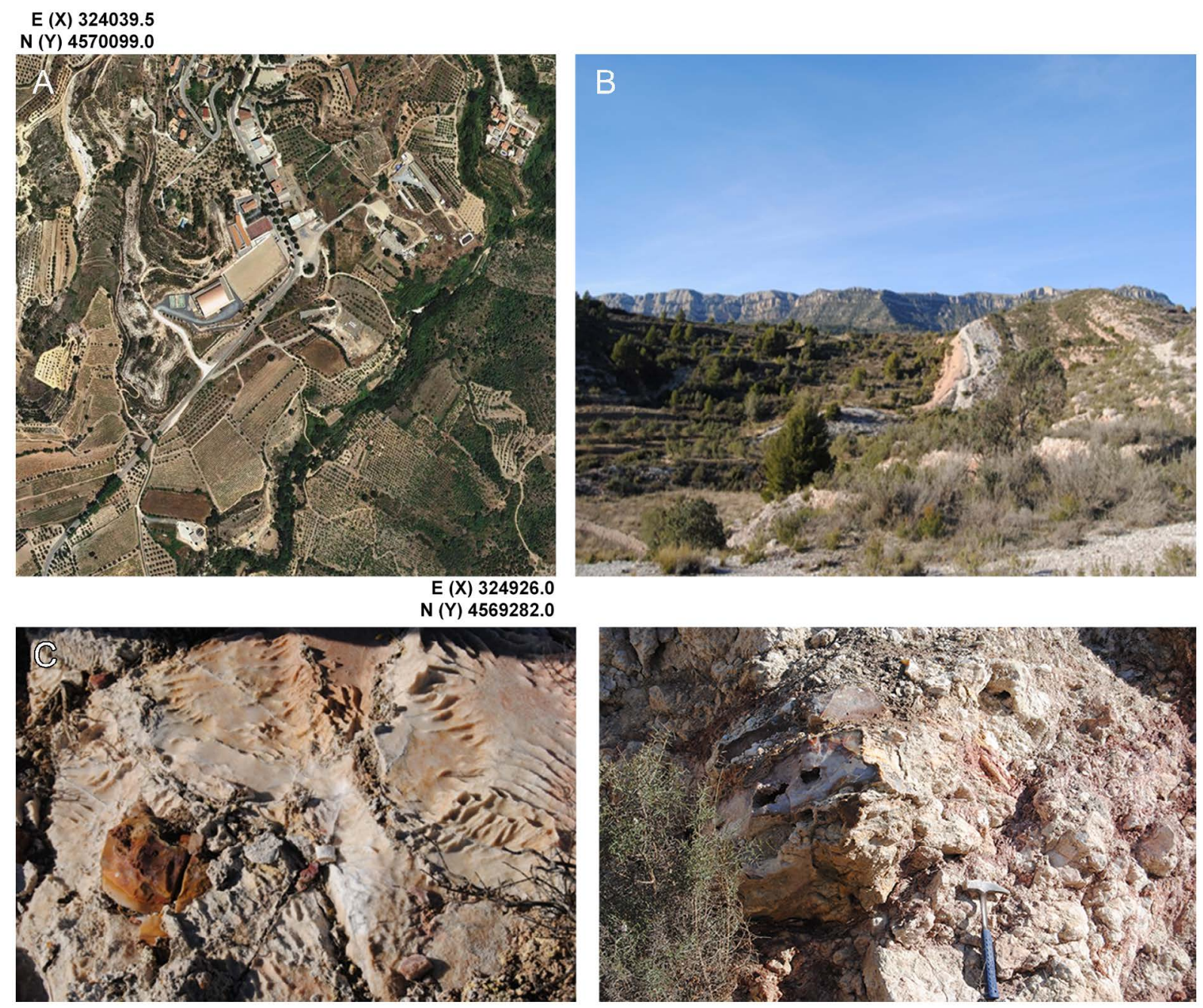

Figure 7. A) Area of the third stop of the Silica Road Trip (UTM 31N-ETRS89). B) General view of the chert outcrop. C) Details of the chert nodules of the area.

\section{The Abric Romaní site (Capellades, Barcelona)}

\subsection{Location}

The Abric Romaní is a rock-shelter situated at the northeast of the Iberian Peninsula, in the town of Capellades, at $50 \mathrm{~km}$ at the north-west of Barcelona (Figure 8). It is $298 \mathrm{~m}$ above sea level, and its geographical coordinates UTM (ETRS89) are $390566 \mathrm{E}$ and $459874 \mathrm{~N}$. It is opened in a travertine formation named Cinglera del Capelló, a travertine escarpment linked to regional aquifer springs formed during the Lower and Middle Pleistocene (Giralt \& Julià 1996) standing approximately at $50 \mathrm{~m}$ above the actual level of the Anoia river. At this point, the Anoia valley forms a narrow gorge that puts in contact the inner part of the Catalonia region with littoral coast, through three big geomorphological units: the Ebro basin, de Prelitoral range and the Prelittoral basin. The abundant prehistoric and historic evidences in the Cinglera del Capelló attests the continuous use of this natural strait.

\subsection{Research history}

We can summarize the history of research in three main phases.

1) The discovery of the site by Amador Romaní in 1909 and the excavations campaigns during the 30's of the 20th Century (Figure 9a). These fieldworks, sponsored by the Institut 
d'Estudis Catalans, were directed by the priest Nobert Font i Sagué and by the mining engineer Lluís Marià Vidal. During this research phase, the Abric Romaní became one of the first sites in the Iberian Peninsula with Mousterian lithic industries.
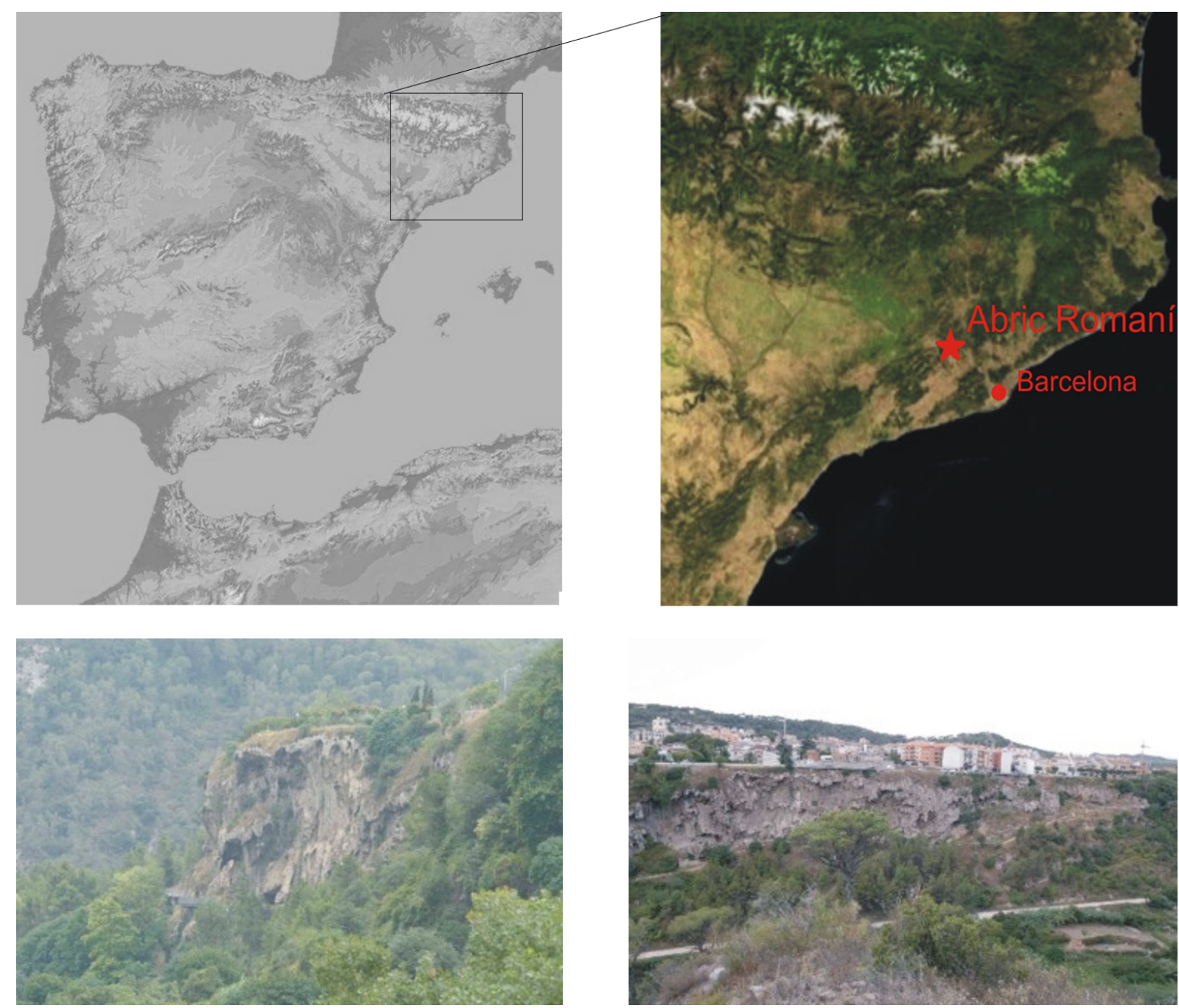

Figure 8. A) Localization of the Abric Romaní site B) General views of the Cinglera del Capelló.

This period ended with the publication of the Abric Romaní findings in the Història de Catalunya by Antoni Rovira i Virgili, based on the Atlas de Prehistòria written by Amador Romaní, compiled in Bartrolí et al. (1995).

2) The second phase corresponds to 1957-1962 and was led by Dr. Eduard Ripoll, motivated by the celebration of the $5^{\text {th }}$ INQUA Congress held in Spain. During this period the cronocultural sequence was reworked, and the Musterian lithic assemblages studied by George Laplace and Henry de Lumley.

3) The last phase, from the 80's of the last century to the present. It is the period of the formation of the actual research team, and the study of the site through a transdisciplinary perspective. Firstly, it was led by a work group associated to the Universitat Autònoma de Barcelona and the Centre de Recerques Paleoecosocials (CRPES) under the direction of Dr. Eudald Carbonell, Artur Cebrià and Dr. Rafael Mora. Secondly, this period was led by a research team from the Universitat Rovira i Virgili of Tarragona, under the direction of Dr. Eudald Carbonell. Finally, the studies are in charge of the same director ascribed to the Institut Català de Paleoecologia Humana i Evolució Social (IPHES). During these years, the whole sequence has been dated, and the site has been uninterruptedly excavated in extension 
(more than $200 \mathrm{~m}^{2}$ ), in order to study the archaeological materials, the structures (combustion structures, wood imprints, etc.) and to document their spatial distribution (Figure 9b).
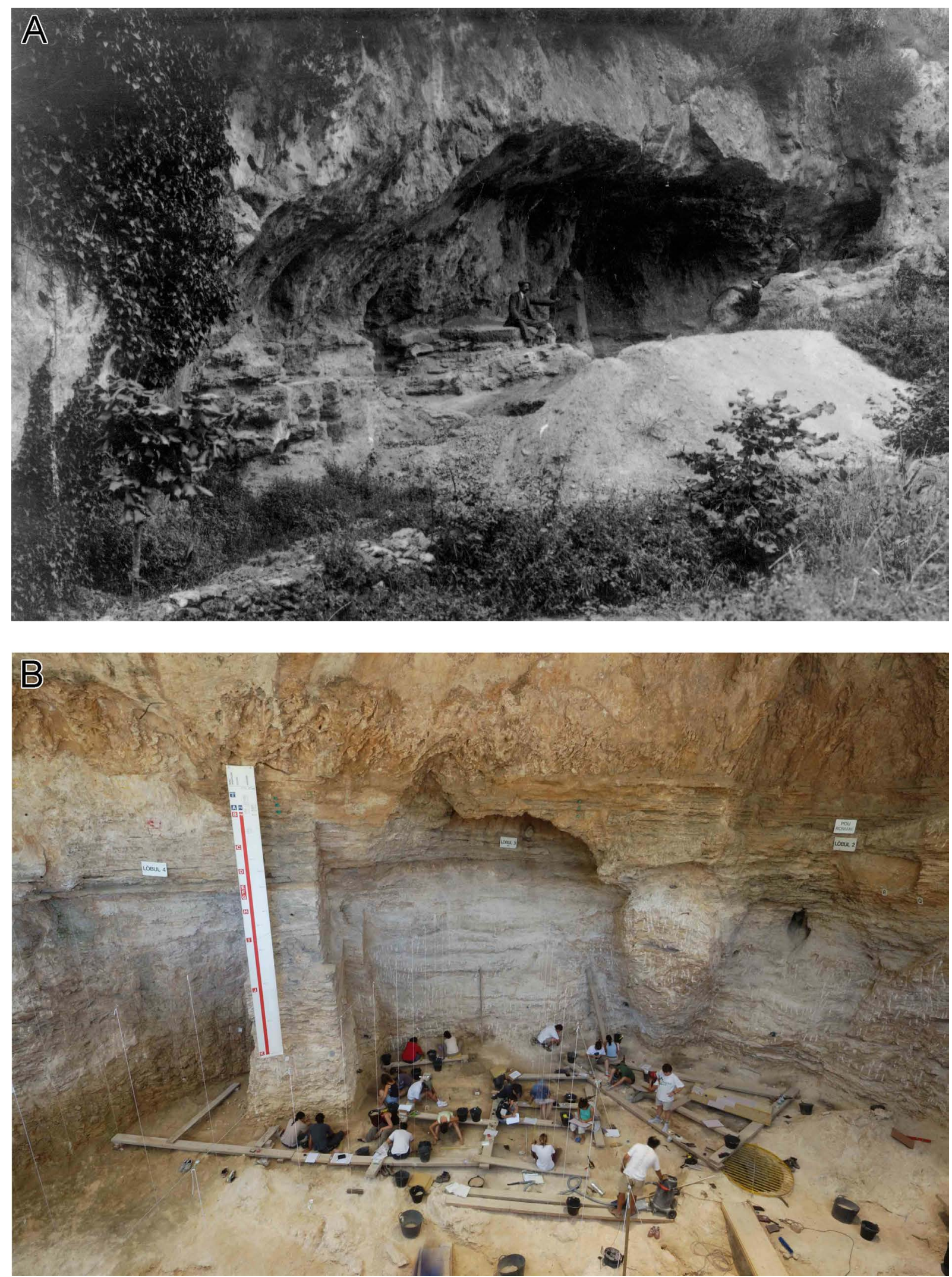

Figure 9. A) Amador Romaní at the site during the first research phase (Bartrolí et al. 1995). B) Image of the actual fieldworks at the Abric Romaní during the excavation of level M (IPHES). 


\subsection{Stratigraphy, chronology and palaeonvironment}

The Abric Romaní presents a 50m stratigraphic succession formed mainly by travertine, sands and silts, where up to 27 archaeological levels have been documented (Carbonell et al. 1994; Sharp et al. 2016). The general sequence is formed by four sedimentary series: platform, palustrine, block fall and terrigenous ones (Figure 10).

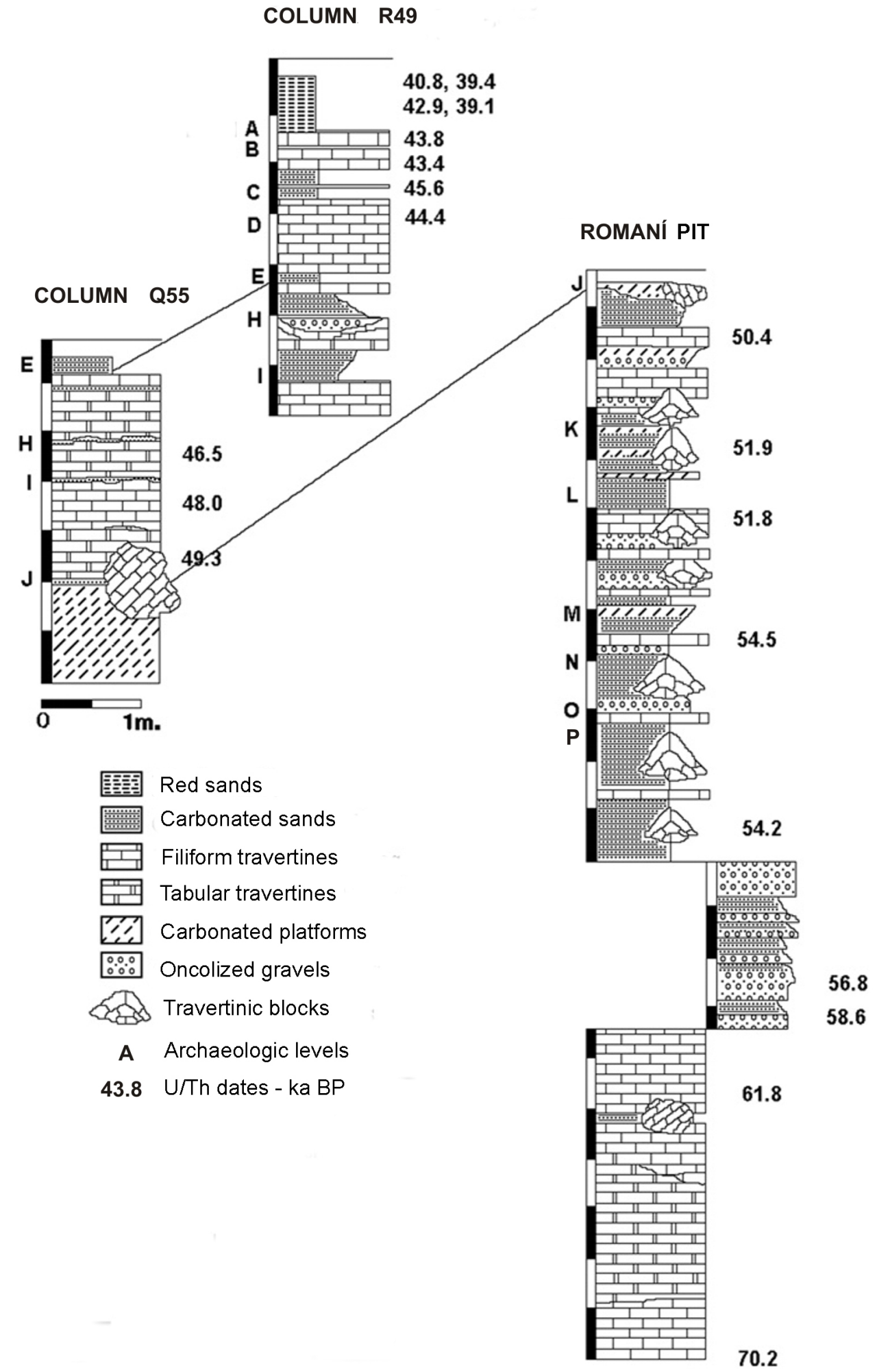

Figure 10. Stratigraphic secuence of the Abric Romaní (modified from Giralt \& Julià 1996). 
The platform series is the main part of the sedimentary sequence, due to the water activity. The highest content of calcium carbonate in the water provoked its precipitation upon the plants and causes the formation of travertine. The palustrine series presents the most variety of facies, and it is defined by the presence or absence of water, generating the formation of paleochannels and gorges. The block fall series are represented by two facies types: plates and blocks. It is generally caused by seismic movements or the collapse of part of the cornice. The terrigenous corresponds to the main series containing the archaeological levels.

The Abric Romaní sequence has provided more than 80 Uranium/Thorium and C14 dates covering a range from 110 to $39 \mathrm{ka} \mathrm{BP}$. These dates associate the Abric Romaní sequence to the isotopic stages 5, 4 and 3 (Sharp et al. 2016), due to a high sedimentation rate, estimated at $0.6 \mathrm{~m}$ per 1000 years (Bischoff et al. 1988; 1994). All the levels are associated to Middle Paleolithic occupations, with the exception of level A that is of Upper Paleolithic (Vaquero et al. 2013).

From a paleoclimatic point of view, five climatic phases have been documented between warm periods and cooler and drier periods. The most representing taxons are Artemisa, Poaceae and Pinus, with the predominance of pine forest in all the sequence (Burjachs et al. 2012).

\subsection{Archaeological assemblage}

The general characteristic of all archaeological levels of the Abric Romani, except for level A (Archaic Aurignacian according to Laplace (1962)) is the fragmentation of the operative sequences, although refitting studies shows that full or almost full knapping sequences can be found in some levels. The main objective of the lithic sequences is to obtain as many knapped products as possible and these are therefore the predominant category in all the archaeological levels of the site. However, cores and retouched objects are scarce in the record, not reaching significant percentages in most of the archaeological levels (Figure 11).

In terms of raw materials, the most used are different varieties of chert, followed by quartz and limestone. Quartzite, porphyry, granite and schist are also sporadically used. The perimeter around the shelter is considered the supplying area for the minority rocks of the assemblages, proposing a local procurement range. The radius for chert procurement is considered regional. It oscillates between $15 \mathrm{~km}$ and $24 \mathrm{~km}$, according the source areas of the most common cherts, the St. Martí de Tous type and to the most distant chert-outcrops, the Panadella type (Gómez de Soler 2016).

Morphotechnical analysis of the cores and knapped products show us that in all the sequence the most used method is the discoid one, identifying also the Levallois method (essentially recurrent centripetal), polyhedral morphologies, cores on flakes and the hierarchical centripetal cores. Regarding the retouched artifacts, the predominance of denticulate in all the sequence is attested (Vaquero 1997; Chacón 2009).

The faunal assemblages are abundant throughout the whole sequence of Abric Romani, identifying more than 13 different taxa. A predominance of Cervus elaphus and Equus ferus, followed by Bos primigenius and Rubicapra pyrenaica has been described in all the sequence.

In terms of taphonomy, the most abundant modifications in the bone assemblages are those related to anthropic activity: cut marks and fractured bones. Cremation is also commonly found and it could be related to specific deliberate activities, ranging from food preparing to cleaning-up activities. Carnivore modifications are almost absent from the faunal assemblage (Rosell 2001; Cáceres 2002; Marín et al. 2017). 


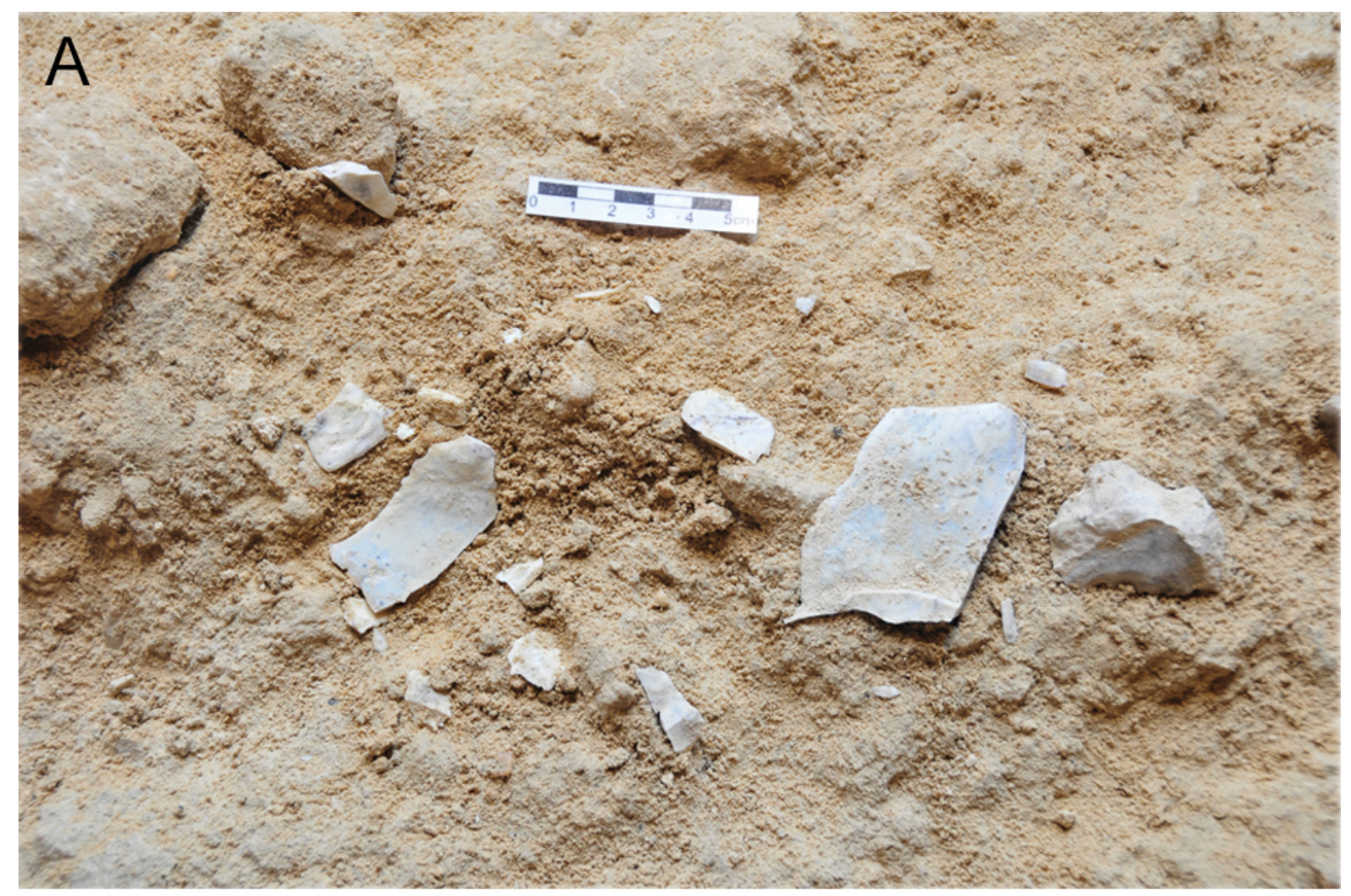

B
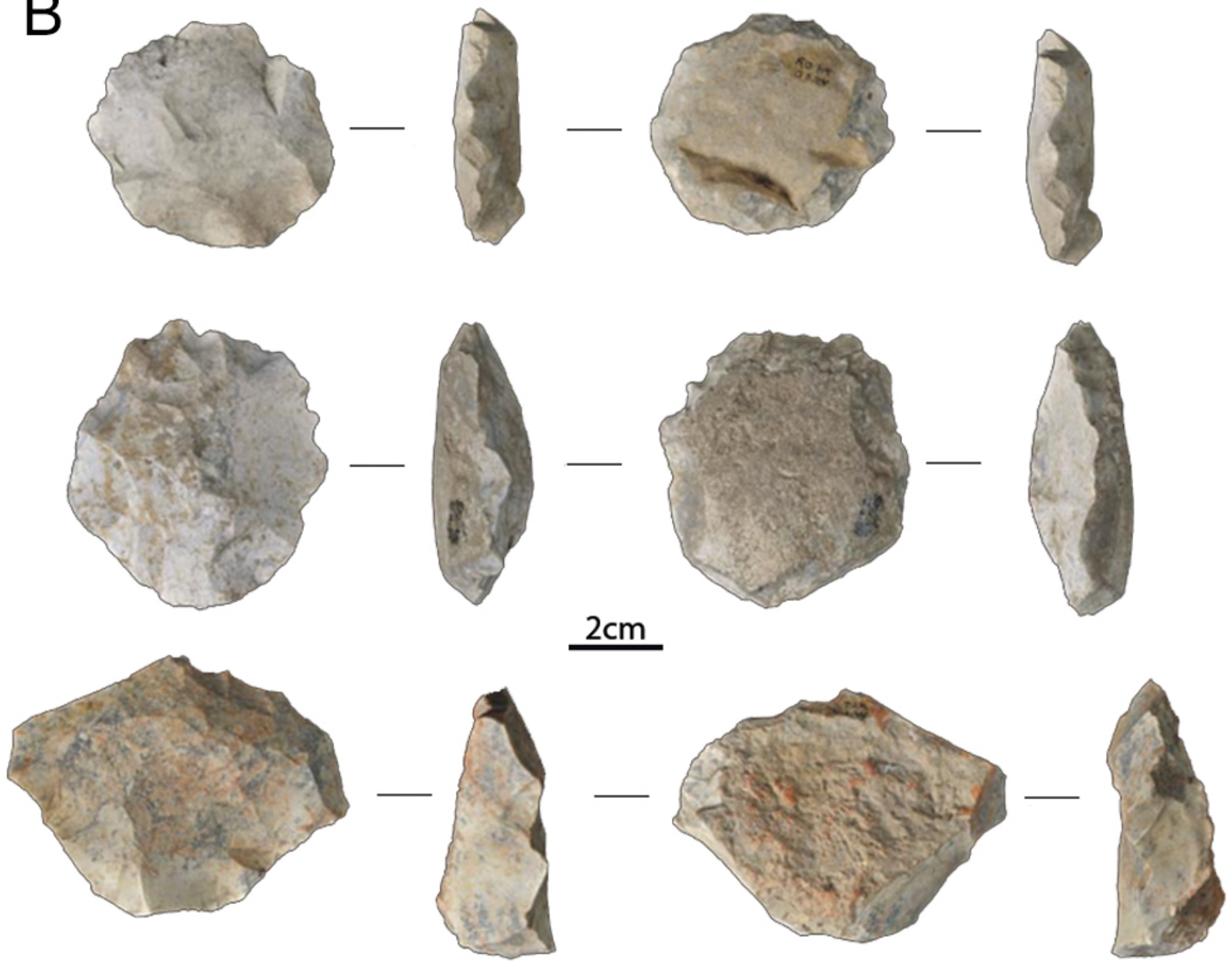

Figure 11. A) Image of a knapping area B) Chert cores from the Level Oa of the Abric Romani (IPHES). 
The combustion structures are also common register documented in the whole sequence, overcoming the 200 structures. The activities carried out by Neanderthals in the Abric Romani were developed around the fire. More than the $80 \%$ of the combustion structures are flat without any kind of preparation. There are also flat combustion structures rounded by rocks, within concavities, in small pits with burned rocks and sediments, and in re-excavated holes. Hearths vertebrate the space and represented and important focus for developing different activities at the site (Vaquero \& Pastó 2001; Vallverdú et al. 2012)).

Concerning wood remains, a high preservation of them is characteristic due to the formation of travertine and the sedimentological conditions. Negatives of non-carbonized wood, positive and negative of carbonized woods have been documented.

All these evidences constitute one of the most complete records to study the residential camps and to trace the economic and social Neanderthal behavior not only in the Iberian Peninsula but in Europe.

\section{Acknowledgements}

The authors want to thank the directors and people involved in the prospecting programmes and fieldwork of the Abric Romaní, especially to Dr. Gema Chacón. This research has been supported by Catalonian Government, under Archaeological and Palaeontological Quadrennial Projects 2014/100574, 2014/100575, 2014/100576, 2014/100482, research group SGR2014-901 (AGAUR), and the Ministry of Economy and Competitiveness of Spain, under projects CGL2016-80000-P and CGL2015-65387-C3-1-P (MINECO/FEDER).

\section{References}

Anadón, P. 1989, Los lagos salinos interiores (atalásicos) con faunas de afinidad marina del Cenozoico de la Península Ibérica. Acta Geológica Hispánica, 24: 83-102. (in Spanish) ("The inner saline lakes (atalassic) with Cenozoic marine affinity fauna from the Iberian Peninsula”) URL: http://revistes.ub.edu/index.php/ActaGeologica/article/view/4444

Bartrolí, R., Cebrià, A., Morales, I., Riu-Barrera, E. \& Vaquero, M. 1995, A frec de Ciencia. L'Atles d'Amador Romaní I Guerra. Ajuntament de Capellades, Capellades, 232 p. (in Catalan) ("Rubbing Science. Amador Romani Guerra's Atlas")

Bischoff, J.L., Julia, R. \& Mora, R. 1988, Uranium-series dating of the Mousterian occupation at Abric Romani, Spain. Nature, 332(6159): 68-70. doi:10.1038/332068a0

Bischoff, J.L., Ludwig, K., Garcia, J.F., Carbonell, E., Vaquero, M., Stafford, T.W. \& Jull, A.J.T. 1994, Dating of the Basal Aurignacian Sandwich at Abric Romaní (Catalunya, Spain) by Radiocarbon and Uranium-Series. Journal of Archaeological Science, 21(4): 541-551. doi:10.1006/jasc.1994.1053

Burjachs, F., López-García, J.M., Allué, E., Blain, H.-A., Rivals, F., Bennàsar, M. \& Expósito, I. 2012, Palaeoecology of Neanderthals during Dansgaard-Oeschger cycles in northeastern Iberia (Abric Romaní): From regional to global scale. Quaternary International, 247: 26-37. doi:10.1016/j.quaint.2011.01.035

Cáceres, I. 2002, Tafonomía de yacimientos antrópicos en Karts. Complejo Galería (Sierra de Atapuerca, Burgos), Vanguard Cave (Gibraltar) y Abric Romaní (Capellades, Barcelona). PhD thesis at Universitat Rovira i Virgili. Tarragona, 661 p. (in Spanish) ("Taphonomy of anthropic sites in Karts. Complejo Galería (Sierra de Atapuerca, Burgos), Vanguard Cave (Gibraltar) and Abric Romaní (Capellades, Barcelona)”) 
Carbonell, E., Giralt, S. \& Vaquero, M. 1994, Abric Romani (Capellades, Barcelone, Espagne): Une importante séquence anthropisée au Pléistocène supérieur. Bulletin de la Sociétè Prehistorique Française, 91(1): 47-55. (in French) (“Abric Romaní (Capellades, Barcelona, Spain): an important anthropized sequence for the Upper Pleistocene”) doi:10.3406/bspf.1994.9703

Chacón, M.G. 2009, El Paleolítico medio en el suroeste europeo: Abric Romaní (Capellades, Barcelona, España), Payre (Rompón, Ardèche, Francia) y Tournal (Bize, Aude, Francia). Análisis comparativo de los conjuntos líticos y los comportamientos humanos. Doctoral thesis. Unpublished. Universitat Rovira i Virgili. Tarragona, 607 p. (in Spanish) ("The Middle Palaeolithic in the southwestern Europe: Abric Romaní (Capellades, Barcelona, España), Payre (Rompón, Ardèche, Francia) and Tournal (Bize, Aude, Francia). Comparative analysis of the lithic assemblages and human behaviours”)

Colombo, F. 1986, Estratigrafía y sedimentología del Paleógeno continental del borde meridional occidental de los catalánides (Provincia de Tarragona, España). Cuadernos de Geología Ibérica, 10: 55-115. (in Spanish) ("Palaeogene continental stratigraphy and sedimentology from the south-western edge of the Catalanids (Tarragona Province, Spain)”)

Colombo, F. \& Vergés, J. 1992, Geometria del margen S.E. de la Cuenca del Ebro: discordancias progresivas en el Grupo Scala Dei. Serra de La Llena. (Tarragona). Acta Geologica Hispanica, 27(V-2 (Homenaje a Oriol Riba Arderiu)): 33-53. (in Spanish) ("Geometry of the SE margin of the the Ebro basin: progressive discordances in the Scala Dei Group. Serra de La Llena (Tarragona)”)

URL: http://revistes.ub.edu/index.php/ActaGeologica/article/view/5028

Giralt, S. \& Julià, R. 1996, The sedimentary record of the Middle-Upper Paleolithic transition in the Capellades area (NE Spain). In: The Last Neandertals, the First Anatomically Modern Humans: A Tale about the Human Diversity (Carbonell, E. \& Vaquero, M., Eds.), Universitat Rovira i Virgili, Tarragona: p. 337-349.

Gómez de Soler, B. 2016, Procedencia del aprovisionamiento lítico durante el Paleolítico medio en el yacimiento del Abric Romaní (Capellades, Barcelona). Niveles M, Oa y P. Universitat Rovira i Virgili, Tarragona, 387 p. (in Spanish) ("Lithic procurement provenance during the Middle Palaeolithic at the Abric Romaní site (Capellades, Barcelona). Levels M, Oa and P”)

Institut Cartogràfic i Geològic de Catalunya (ICGC) 2016a, Mapa geològic comarcal de Catalunya 1:50.000, UTM 31N (ETRS89). Retrieved 15 August 2016. (in Catalonian) (“Geologic Map of Catalunya, 1:50,000”) URL: http://www.icgc.cat/Administracio-iempresa/Descarregues/Cartografia-geologica-i-geotematica/Cartografiageologica/Mapa-geologic-comarcal-de-Catalunya-1-50.000

Institut Cartogràfic i Geològic de Catalunya (ICGC) 2016b, VISSIR v3.26 - Ortofoto 1:25.000, UTM 31N (ETRS89). Retrieved 15 August 2016. (in Catalonian) ("VISSIR v3.26 - Ortophoto 1:25,000”) URL: http://www.icgc.cat/Administracio-iempresa/Descarregues/Cartografia-geologica-i-geotematica/Cartografiageologica/Mapa-geologic-comarcal-de-Catalunya-1-50.000

Laplace, G. 1962, Le Paleolithique Superieur de l'Abri Romani. L'Anthropologie, 66: 36-43. (in French) ("The Upper Palaeolithic from the Abric Romaní”) 
Marín, J., Saladié, P., Rodríguez-Hidalgo, A. \& Carbonell, E. 2017, Ungulate carcass transport strategies at the Middle Palaeolithic site of Abric Romaní (Capellades, Spain). Comptes Rendus Palevol, 16(1): 103-121. doi:10.1016/j.crpv.2015.11.006

Rosell, J. (2001). Patrons d'Aprofitement de les biomasses animals durant el Pleistocè Inferior i Mig (Sierra de Atapuerca) i Superior (Abric Romaní, Barcelona). Doctoral thesis. Unpublished. Univesritat Rovira i Virgili. Tarragona, 338 p. (in Catalan) ("Use patterns of biomass animals during the Lower and Middle Pleistocene (Sierra de Atapuerca) and Upper Pleistocene (Abric Romaní, Barcelona)”)

Sharp, W.D., Mertz-Kraus, R., Vallverdu, J., Vaquero, M., Burjachs, F., Carbonell, E. \& Bischoff, J.L. 2016, Archeological deposits at Abric Romaní extend to 110 ka: U-series dating of a newly cored, 30 meter-thick section. Journal of Archaeological Science: Reports, 5: 400-406. doi:10.1016/j.jasrep.2015.12.015

Soto, M. 2015, Áreas y estrategias de aprovisionamiento lítico de los últimos cazadoresrecolectores en las Montañas de Prades (Tarragona). Doctoral thesis thesis no. T 230-2016 at the Departamento de Història i Història de l'Art, Universitat Rovira i Virgili, Tarragona, 715 p. (in Spanish) ("Areas and lithic procurement strategies among the last huntergatherers in the Prades range (Tarragona)") URL: http://www.tdx.cat/handle/10803/348554

Vallverdú, J., Alonso, S., Bargalló, A., Bartrolí, R., Campeny, G., Carrancho, Á., Expósito, I., Fontanals, M., Gabucio, J., Gómez, B., Prats, J.M., Sañudo, P., Solé, À., Vilalta, J. \& Carbonell, E. 2012, Combustion structures of archaeological level $\mathrm{O}$ and mousterian activity areas with use of fire at the Abric Romaní rockshelter (NE Iberian Peninsula). Quaternary International, 247: 313-324. doi:10.1016/j.quaint.2010.12.012

Vaquero, M. 1997, Tecnología lítica y comportamiento humano: organización de las actividades técnicas y cambio diacrónico en el Paleolítico Medio del Abric Romaní (Capellades, Barcelona). Doctoral thesis. Unpublished. Universitat Rovira i Virgili. Tarragona, 872 p. (in Spanish). Lithic technology and human behaviour: organization of the technical activities and diachronical change in the Middle Palaeolithic of the Abric Romaní (Capellades, Barcelona)”)

Vaquero, M. \& Pastó, I. (2001). The definition of spatial units in Middle Palaeolithic sites: the Hearth-related assemblages. Journal of Archaeological Science, 28, pp. 1209-1220. doi:10.1006/jasc.2001.0656

Vaquero, M., Allué, E., Bischoff, J.L., Burjachs, F. \& Vallverdú, J. 2013, Environmental, depositional and cultural changes in the Upper Pleistocene and early Holocene: the Cinglera del Capelló sequence (Capellades, Spain). Quaternaire, 24(1): 49-64. doi:10.4000/quaternaire.6481

Vilaseca, S. 1953, Las industrias del sílex Tarraconenses. Consejo Superior de Investigaciones Científicas, Instituto Rodrigo Caro, Madrid, 526 p. (in Spanish) ("The chert lithic industries from Tarragona”) 


\title{
La ruta del sílex: Guía de la excursión
}

\author{
María Soto ${ }^{1,2}$, Bruno Gómez de Soler ${ }^{1,2}$ \\ 1. Institut Català de Paleoecologia Humana i Evolució Social (IPHES). C/Marcel.lí Domingo s/n (Edifici W3), \\ Campus Sescelades, 43007, Tarragona, España. \\ 2. Àrea de Prehistoria, Universitat Rovira i Virgili (URV), Avinguda Catalunya, 35, 43002, Tarragona, España. \\ Email: Soto: sotoquesadamaria@gmail.com; Gómez de Soler: bgomez@iphes.cat
}

\begin{abstract}
:
Durante el 10th International Symposium on Knappable Materials (ISKM) celebrado en Barcelona (España) en septiembre de 2015, se programó una excursión denominada "La Ruta del sílex". Esta salida incluyó la visita a distintos afloramientos con sílex próximos al Macizo del Montsant (Tarragona, NE Península Ibérica), y al yacimiento de Paleolítico Medio del Abric Romaní (Capellades, Barcelona), como localizaciones importantes para la Prehistoria del NE de la Península Ibérica.

Este trabajo presenta las notas facilitadas a los asistentes durante la excursión. La guía se estructura en: 1) una breve introducción al marco geológico del Macizo del Montsant, localizado en el margen meridional de la Depresión Central Catalana. Ésta incluye la definición de su secuencia deposicional, desde el Paleozoico al Cenozoico, y la referencia a algunos puntos de interés con vistas panorámicas de la zona y silicificaciones disponibles, que supusieron un importante foco de aprovisionamiento de materias primas para distintas ocupaciones paleolíticas desde el Pleistoceno inferior.2) LA presentación general del yacimiento de Paleolítico medio del Abric Romaní, incluyendo una breve introducción a sus tres fases de investigación, iniciadas a principios del S.XX, la descripción de su secuencia estratigráfica con 50 metros de potencia y en la que se han identificado 27 niveles arqueológicos por el momento, y los rasgos principales de los conjuntos arqueológicos recuperados en él.
\end{abstract}

Keywords: materias primas líticas; sílex; Macizo del Montsant; Complejo Ulldemolins; Paleolítico medio; Abric Romaní 